\author{
Anna Jaśkiewicz \\ University of Lodz \\ Faculty of Geographical Sciences \\ Institute of Geography of the City and Turism \\ anna.jaskiewicz92@gmail.com
}

\title{
PERCEPTION OF THE ŁÓDŹ INDUSTRIAL ARCHITECTURE ROUTE BY ITS INHABITANTS: AN EXAMPLE OF SOCIAL PARTICIPATION IN TOURISM RESEARCH
}

\begin{abstract}
An attempt to utilise this has been the creation of the Łódź Industrial Architecture Trail, bringing together buildings related to its industrial past. According to the author, to make the trail a tourist attraction, the first people who should be aware of its value are the city's inhabitants. The survey confirmed the very important role of social participation in creating the image of a city, and providing the basis for further work on its improvement and promotion. The article does not cover social participation as part of the process of development, but can serve as a contribution to a discussion of the role of a city's inhabitants in shaping its tourism attractions. At the same time, the article confirms that social participation is an extremely important element of tourism research and forms an introduction to its effective use in practice.
\end{abstract}

Keywords: Łódź Industrial Architecture Trail, social research, social participation, industrial tourism, post-industrial tourism, revitalization.

\section{INTRODUCTION}

Post-industrial areas are a huge legacy in Łódź, as a result of the large-scale capitalist development of the textile industry in the $19^{\text {th }}$ and early $20^{\text {th }} \mathrm{c}$. In recent years, more and more areas and sites with historical industrial functions have been revitalized and adapted to serve a tourism function. This is due to the growing interest in industrial tourism and the wish to get to know one's own country and city. Therefore, it may be assumed that industrial areas have a significant tourism value for Łódź.

Residents are a group that are in constant touch with the urban fabric. Social participation, which is defined as the active participation of city inhabitants in planning and decision-making, is a very important part of their immediate environment. In this process an important role is played by social consultation which can take place directly, e.g. meetings and workshops, or indirectly e.g. surveys, referenda and discussion forums. These enable residents to influence local community decisions and build trust with authorities (HAUSNER 1999). The subject of inhabitants' involvement in public affairs has often been taken up in the literature (e.g. CZAPIŃSKI 2009, FRYKOWSKI 2005,
PUTNAM 1995, SZAFRAŃSKA 2008, 2010). Social participation is an extremely important element of tourism research and the basis for its efficient development in practice.

In the author's opinion, an inhabitant of Łódź is aware of the cultural potential of the city through its industrial heritage. Perhaps this is a 'perverse' assumption, but if the city's inhabitants do not positively perceive the cultural heritage of their immediate surroundings, they will not create tourism attractions appreciated by a wider audience. It is the inhabitants, in an age when social opinions are an increasingly important factor in city management, who have the potential to influence the shaping of their surrounding space. This is evidenced by projects implemented within the budgets of citizens. Therefore, the author considers it appropriate to conduct a survey, aimed at getting to know their opinions on the Industrial Architecture Route and on prospects for its development. This research could be used by those responsible for building an image of the city and to create a concept for promoting Łódź in the context of its industrial heritage. 
The survey was conducted using internet forums on the Facebook social network, consisting of residents of particular districts and estates in Łódź from the beginning of November 2015 to the end of January 2016. This made it possible to reach a large number of people in a relatively short period of time. 300 questionnaires were filled in. Respondents were selected by the quota method where the key variable was the neighbourhood, enabling representation of all parts of the city: 84 from Bałuty, 72 from Górna, 57 from Polesie, 57 from Widzew and 30 from Śródmieście participated in the survey. Respondents were selected by means of 'accessibility choice' (BABBIE 2005, FRANKFORT-NACHMIAS 2001). The author's assumption was to trace generalised opinions on the trail according to the respondents' location in geographical space. It had been hypothesized that the residents of the districts in which the post-industrial sites are located will appreciate their value better through daily interaction. The second hypothesis assumed that it was such inhabitants who appreciate their potential. The author was aware that the research was not representative, and on that basis, we cannot talk about the entire population. However, she considered that, in the context of the creation of a new tourism attraction, surveys were justified and could provide an initial step to further develop the idea of using existing heritage.

\section{INDUSTRIAL TOURISM AS A TYPE OF CULTURAL TOURISM}

The dynamic changes taking place in modern tourism, due to an increasing public awareness of the need to preserve both cultural and natural heritage, results from the increased level of education of the citizens of Western Europe and influences changes in motives for tourism trips. Based on contemporary trends in tourist behaviour, a new form of cognitive tourism has emerged as a part of cultural tourism - industrial tourism (OCHMAŃSKI 2014). Due to a lack of terminological specificity, the terms industrial tourism, postindustrial tourism and industrial heritage tourism are interchangeable (DEREK 2010). In the literature there are many definitions of these terms.

H. HANDSZUH (2005, pp. 30-31) defines industrial heritage as "a product based on the use inherited from previous generations as well as contemporary places, buildings, spatial systems, devices, tools, sites, Production processes and associated lifestyles and traditions, art and its products that bear witness to the development of industry and technology both in the past and in the present".
According to the definition of A. MIKOS V. ROHRSCHEIDT (2008, p. 121), cultural tourism of industrial sites is "tourist travel, mainly focused on exploring historical or active sites connected with the extraction of raw materials, mass production, technology and industrial landscapes, provided that the leading aspect of these journeys or their main motive is the history of works, sites and machines, or the historical development of technological processes and products. Personal experience is also important, finding industry, production and technology in authentic places, their history and current business".

Similarly, industrial heritage tourism was defined by A. STASIAK (2009), recognizing that these terms are understood as journeys in which the main and often the only goal is to explore industrial heritage.

As defined by M. DEREK (2010, p. 188), industrial tourism is "a form of tourism that aims to explore areas where industry has historically grown, as well as sites and equipment related to the development of technology and industry as industrial heritage of a given area as well as a tour of today's functioning companies".

A precise division of the types of tourism related to industry was made by M. KRONENBERG (2007):

- industrial tourism, which "includes tourism activities at industrial sites related to knowledge of current production processes",

- post-industrial tourism, which "includes tourist activities in areas where the former production function is no longer found but there are preserved traces, such as factory buildings",

- industrial heritage tourism, which "includes tourism activities in areas where heritage is the main attraction and its recognition is the main motive of a tourist's visit".

Due to inaccuracies in the use of terminology in this, this article has decided to use these terms interchangeably.

\section{THE BIRTH OF INDUSTRIAL TOURISM}

The idea of tourist and recreational use of land and post-industrial sites is relatively new. It appeared in the 1970s in Western Europe. Its cause was progressive deindustrialisation which caused the necessity to reflect on what to do with closed factories and how to manage the space occupied by them (JEDDRYSIAK 2011).

Interest in engineering monuments first appeared in countries with rich traditions in industrial development such as Great Britain, France, Germany and 
Sweden. It was in these countries that international contacts were established in the field of industrial and technological monument protection (JASIUK 2008).

The beginnings of industrial heritage were in the United Kingdom, where the industrial revolution had begun. The problem of how to use post-industrial sites intensified particularly in the 1950s and 1960s, and led to an increase in the popularity of industrial archaeology. Its pioneers were interested in these monuments and convinced the public that they were valuable cultural heritage (JĘDRYSIAK 2011). In addition, it was also a time of reflection on the negative impact of many on the environment and the ability to switch to more modern technologies. This led to the liquidation of many factories using traditional production methods (ORŁOWSKI 2008). Instead of destroying the sites, they were revitalized. Such initiatives were favoured by state policy, which financially supported revitalization by promoting achievements. Such an approach quickly took off in the United States and Germany (JĘDRYSIAK 2011).

With the transformation of industrial into modern society, former production methods have become an object of interest to tourists. Guided tours of factories, and museums of science and technology began to be organized. Appreciation of the artistic and cultural value of such sites has become an impetus for the development of cultural heritage tourism (JĘDRYSIAK 2011).

One of the first such activities was the revitalization of the Belgian Blegny-Mines in the 1980s. A theme park and a sports and recreation center with a hotel were built on the site. Another pioneering example is the Ruhr area in Germany, where a network of leisure sites, recreational areas, research and service parks, as well as technology centers and business incubators has been established. The opening of buildings has led to a dynamic increase in the number of examples of tourist uses of post-industrial facilities (KRONENBERG 2012). Other examples include 'Caphouse' coal mine in Yorkshire, the Castlefield district in Manchester, St. Catherine Docks in London, Zollverein coal mine and coking plant in Essen, Sachsen mine in Hamm, Lassie rice mill and De Adelaar soap factory in the Netherlands (JĘDRYSIAK 2011).

These examples demonstrate the appreciation of the value of post-industrial areas by European states and their re-use for educational, recreational and tourist purposes. Interest in former culture, which is becoming increasingly popular, combined with its great potential, is a testament to the successful prospects of post-industrial tourism development in Poland and Łódź (JĘDRYSIAK 2011).

\section{4. ŁÓDŹ INDUSTRIAL ARCHITECTURE TRAIL}

Organizing sites and connecting them into a coherent product gave rise to the trail. Z. KRUCZEK (2007) considered the route needs to be a tourist route which does not always have to be marked. It leads to the most attractive places or sites while preserving safety and security. In recent years, tourist routes have been started in Poland as a type of tourism product. J. KACZMAREK, A. STASIAK \& B. W€ODARCZYK (2010, p. 142) set the definition of a tourist trail, according to which it is "a special case of a tourist product - a place (linear, banded, zonal). It consists of many places or sites connected with an overarching idea, usually marked (walking, water, car, trails etc.) and with differing tourist infrastructure along the route". Among trails, there is a tourist-cultural group whose idea is to focus the route around the theme of culture. Cultural and thematic trails are often used interchangeably in the literature as all existing cultural routes have a narrower or broader theme. It is also possible to develop linear tourism 'penetration' of a cultural nature but not linked by one single coherent theme. 'Multi-thematic' is one term is used to describe these cultural routes, multicultural heritage trails is another (MIKOS V. ROHRSCHEIDT 2010). For the purpose of the article, it was decided to treat the terms cultural trail and thematic trail as the same. J. TOMCZAK (2013, pp. 49-51) adopts the following definition of a thematic route: "...thematic route is an integrated and managed linear recreational 'penetration', consisting of sites represent-ing a given theme in space, connecting routes and elements of the accompanying offer, all of them may be able to have a relationship with the theme. The trail should make it possible to know and understand the nature of the subject, and to facilitate tourism through appropriate development of the trail, allowing visitors to easily navigate and gain information about it and its components. The thematic path thus creates an integral entity, concentrating the visitor's interest on a specific subject, through the prism of which the surrounding space is perceived. The content of the trail is therefore the most important, and to a lesser extent its designation and elements of development."

It is therefore justified to recognize the Industrial Architecture Route as an example of a thematic route. At the same time, a thematic route connecting elements of interest to industrial tourism should be considered as an industrial thematic route.

The Łódź Industrial Architecture Trail has 27 sites, most of which have been revitalized and adapted to new functions (Table 1). A walk along the trail allows you to learn the history of the city, a powerhouse of the textile industry. 
Table 1. Sites located on the Łódź Industrial Architecture Trail

\begin{tabular}{|c|c|c|c|c|c|}
\hline \multirow{2}{*}{ No. } & \multirow{2}{*}{ Name } & \multirow{2}{*}{ Address } & \multicolumn{2}{|r|}{ Function } & \multirow{2}{*}{$\begin{array}{c}\text { Revi- } \\
\text { talisa- } \\
\text { tion }\end{array}$} \\
\hline & & & original & present & \\
\hline 1 & Ludwik Geyer's White Factory & $\begin{array}{l}\text { Piotrkowska Str. } \\
282\end{array}$ & Factory & $\begin{array}{l}\text { Museum, open-air museum, } \\
\text { restaurant }\end{array}$ & + \\
\hline 2 & $\begin{array}{l}\text { Fryderyk Wilhelm Schweikert } \\
\text { Factory }\end{array}$ & $\begin{array}{l}\text { Wólczańska Str. } \\
215 \\
\end{array}$ & Factory & Technical University of Łódź & + \\
\hline 3 & Scheibler Industrial Warehouses & $\begin{array}{c}\text { Tymienieckiego } \\
3 / 5\end{array}$ & Industrial warehouses & $\begin{array}{l}\text { Offices of organizations } \\
\text { and businesses related to } \\
\text { culture }\end{array}$ & + \\
\hline 4 & $\begin{array}{l}\text { Scheibler Industrial Power } \\
\text { station }\end{array}$ & Tymienieckiego 5 & Power station & $\begin{array}{l}\text { Offices of organizations } \\
\text { and businesses related to } \\
\text { culture }\end{array}$ & + \\
\hline 5 & Tytus Kopisch Bleachery & Tymienieckiego 5 & \begin{tabular}{|l|}
$\begin{array}{l}\text { Residential-industrial } \\
\text { building }\end{array}$ \\
\end{tabular} & The Municipal Office of Łódź & + \\
\hline 6 & Markus Silberstein Factory & $\begin{array}{c}\text { Piotrkowska } \\
242 / 250\end{array}$ & Factory & Shopping areas & + \\
\hline 7 & Zygmunt Richter Factory & $\begin{array}{c}\text { Stefanowskiego } \\
17\end{array}$ & Factory & Commercial and service areas & - \\
\hline 8 & $\begin{array}{l}\text { Karol Scheibler New Textile } \\
\text { Mill } \\
\end{array}$ & Kilińskiego 187 & Factory & None & - \\
\hline 9 & Scheibler Industrial Hospital & Milionowa 14 & Hospital & Hospital & + \\
\hline 10 & $\begin{array}{l}\text { Karol Scheibler Spinning } \\
\text { Mill }\end{array}$ & Tymienieckiego 25 & Factory & Residential buildings & + \\
\hline 11 & Scheibler Fire Station & $\begin{array}{c}\text { Tymienieckiego } \\
30 \\
\end{array}$ & Fire station & Office & + \\
\hline 12 & Scheibler Workers' Housing & Księży Młyn estate & Residential buildings & Residential buildings & $+/-$ \\
\hline 13 & Scheibler Industrial School & $\begin{array}{c}\text { Księży Młyn } \\
13 / 15 \\
\end{array}$ & School & $\begin{array}{l}\text { Academic Design Center } \\
\text { (work is underway) }\end{array}$ & + \\
\hline 14 & Scheibler Industrial Shop & Księży Młyn 14 & Shop & $\begin{array}{l}\text { Headquarters of 'Księży } \\
\text { Młyn' publishing house, } \\
\text { restaurant }\end{array}$ & + \\
\hline 15 & Grohmann Barrels & Targowa 46 & Gateway to factory & None & + \\
\hline 16 & 'Centrala' Scheibler Factory Unit & $\begin{array}{c}\text { Zwycięstwa Squar } \\
2 \\
\end{array}$ & Factory & Service sites & - \\
\hline 17 & Winkler \& Gaertner Factory & $\begin{array}{c}\text { Sienkiewicza } \\
82 / 84\end{array}$ & Factory & Business Centre & + \\
\hline 18 & Józef Balle Factory & Sienkiewicza 72 & Factory & Media offices & + \\
\hline 19 & $\begin{array}{l}\text { Eódź joint-stock company of } \\
\text { thread manufacturers }\end{array}$ & Niciarniana 2 & Factory & Factory & - \\
\hline 20 & $\begin{array}{l}\text { Juliusz Heinzl workers' } \\
\text { housing }\end{array}$ & Tuwima $23 / 25$ & Residential buildings & Residential buildings & - \\
\hline 21 & EC1 Power station & Targowa $1 / 3$ & Power station & Cultural and artistic center & + \\
\hline 22 & Fryderyk Göldner Factory & $\begin{array}{l}\text { Rewolucji } 1905 \text { r. Str. } \\
52\end{array}$ & Factory & $\begin{array}{l}\text { Academy of Humanities and } \\
\text { Economics }\end{array}$ & + \\
\hline 23 & Izrael Poznański 'Empire' & Ogrodowa 17 & Industrial complex & $\begin{array}{l}\text { Shopping and cultural- } \\
\text { entertainment center }\end{array}$ & + \\
\hline 24 & $\begin{array}{l}\begin{array}{l}\text { Izrael Poznański workers' } \\
\text { houses }\end{array} \\
\end{array}$ & $\begin{array}{c}\text { Ogrodowa } 24, \\
26,28\end{array}$ & Residential buildings & Residential buildings & $+/-$ \\
\hline 25 & Ernst Wever Factory & Kopernika 3 & Factory & $\begin{array}{l}\text { Commercial and service } \\
\text { areas }\end{array}$ & + \\
\hline 26 & Juliusz Kindermann Factory & Łąkowa $23 / 25$ & Factory & Hotel & + \\
\hline 27 & Adolf Daube Factory & $\begin{array}{c}\text { Wólczańska } \\
128 / 134 \\
\end{array}$ & Factory & Business Centre & + \\
\hline
\end{tabular}

${ }^{1}$ The table shows which sites were revitalized ('+' revitalized, '-' not revitalized, '+/-' partly revitalized).

Source: author. 
1 - Ludwik Geyer's White Factory 2 - Fryderyk Wilhelm Schweikert Factory 3 - Scheibler Industrial Warehouse 4 - Scheibler Industrial Powerhouse 5 - Tytus Kopisch Bleanchery 6 - Markus Silberstein Factory 7 - Zygmunt Richter Factory 8 - Karol S. Scheibler New Textile Mill 9 - Scheibler Industrial Hospital 10 - Karol S Scheibler Spinning Mill

11 - Scheibler Fire Station

12 - Scheibler Workers' Houses

13 - Scheibler Workers Houses

14 Scheibler Industrial Shop

15 - Grohmann Barrels

16 - "Central "- Scheibler Factory Unit

17 - Winkler \& Gaertner Factory

18 - Józef Balle Factory

19 - Factory of Lodz joint-stock company of threads

20 - Juliusz Heinzl Workers' Houses

21 - EC1 Power station

22 - Ferdynand Goldner Factory

23 - Izrael K. Poznański Empire

24 - Izrael K Poznański Workers' Houses

5 - Ernst Wever Factory

6 - Juliusz Kindermann Factory; 27 - Adolf Daube Factory
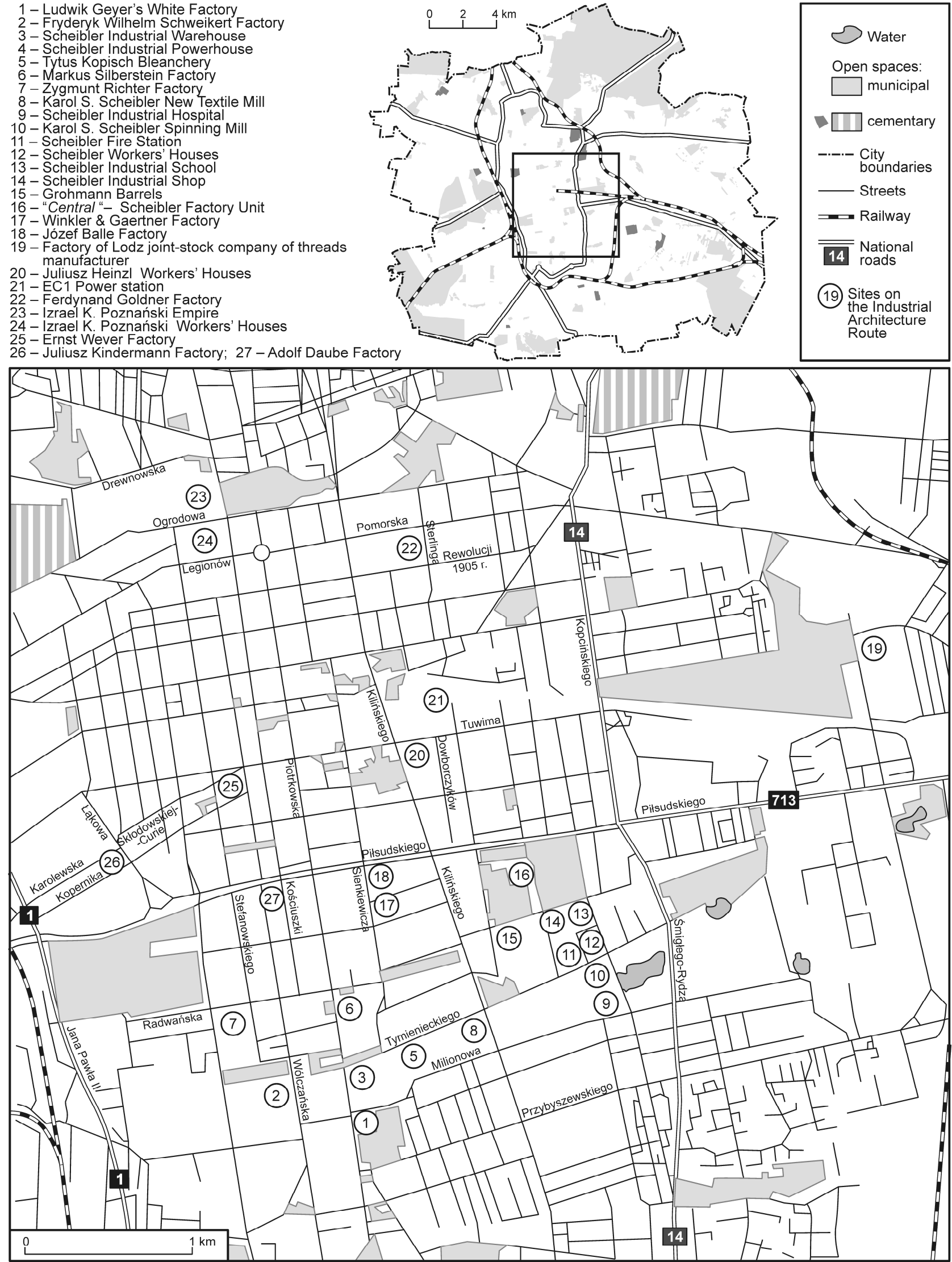

Fig. 1. Sites on the Industrial Architecture Route of Łódź Source: author 
The Industrial Architecture Trail is located in the center of Łódź. The trail does not have a planned route or development, only points (Fig. 1) located in all districts of the city (Fig. 2).

Among the sites located in Śródmieście (6), there are five factories: Markus Silberstein, Winkler and Gaertner, Joseph Balle, Ferdinand Göldner, Adolf Daube along with Julius Heinzel workers' housing.

Another district is Polesie where there were four factories: Fryderyk Wilhelm Schweikert, Zygmunt Richter, Ernst Wever and Julius Kindermann.

The Bałuty district has two sets of sites connected with the Israel Poznanski 'Empire' (today Manufaktura) and workers' housing.

The only one located in the Górna District is Ludwik Geyer's 'White Factory'.

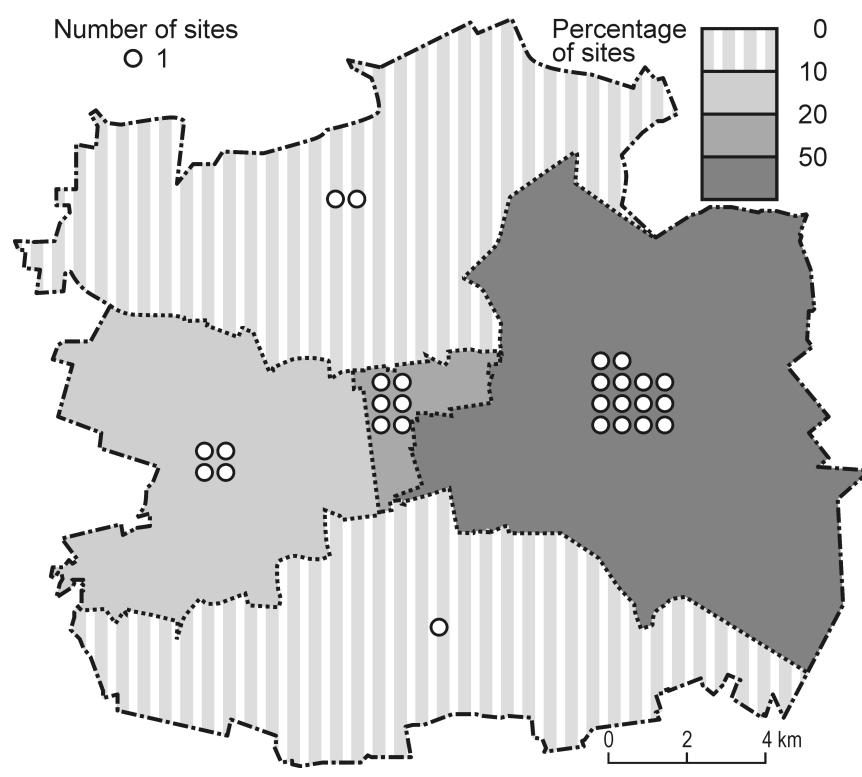

Fig. 2. Location of trail facilities in Łódź Source: author

Łódź Town Hall is promoting the Industrial Architecture Route. The basic promotional material is a brochure for the route, available at tourist information points and some Łódź accommodation facilities. The brochure briefly describes all the sites on the trail along with their location of the map and the history of the largest Łódź industrial families. The brochure is also available on the website of the Town Hall, in the section dedicated to tourism. The trail, in June 2010, was also covered by the Odkoduj Łódź project. The contractor was the City of Łódź, and it was undertaken by Mobile MS. This was the first such project in Poland. The idea was to provide users with additional information about sites via photocodes.

\section{PERCEPTION OF THE ŁÓDŹ INDUSTRIAL ARCHITECTURE ROUTE BY INHABITANTS}

Among the surveyed group, 68\% were women and $32 \%$ men. There were seven age groups; the largest (41\%) was between 20 and 29, 17\% were 30-39, 14\% younger than 19, 12\% - 40-49, and 10\% - 50-59 while only $5 \%$ were between 60 and 69 . None was over 70 .

The majority of respondents had higher education (35\%), many had completed secondary education (24\%) while the rest had undergraduate $(16 \%)$, post-secondary $(9 \%)$ or just primary $(8 \%)$ education. The lowest had lower secondary $(5 \%)$ or vocational $(3 \%)$. More than half were employed (53\%), next came school and HE students (36\%) while a small percentage were retired $(5 \%)$, unemployed $(4 \%)$ or pensioners $(1 \%)$. Both education and occupational status were influenced by age.

More than half $(54 \%)$ said they had heard about the Łódź Industrial Architecture Route the others (45\%) that they had not. Probably some respondents answered the question, not quite aware of the route, but merely identified the city with post-industrial sites. This is confirmed by the question of how they learned about the trail, ten respondents who previously replied that they had heard of the trail gave no response (Figure 3).

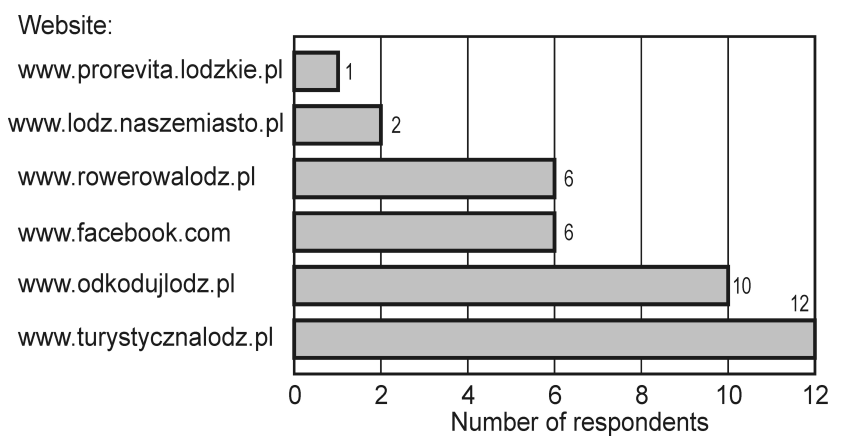

Fig. 3. Source of trail information

Source Figs 3-9: author, based on questionnaire surveys

The most popular source of knowledge about the trail were friends (33\%) which confirms the role of the so-called whispering market in the dissemination of information. Many respondents also pointed to the use of the website $(23 \%$, Fig. 4) and tourist information $(15 \%)$. Sources of information included the press $(8 \%)$, television $(7 \%)$, leaflets and brochures $(6 \%)$, and radio $(1 \%)$. Twenty respondents $(8 \%)$ indicated other sources such as school, husband, college. 


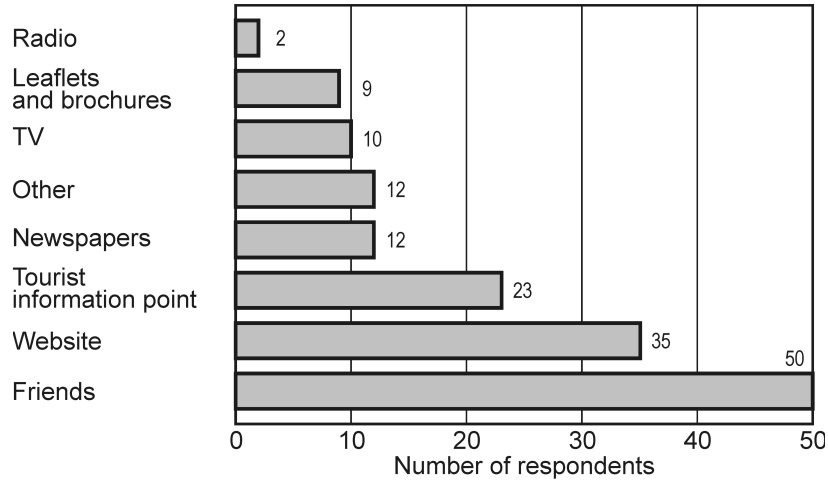

Fig. 4. Web pages as a source of trail information

The most frequently referenced website was Łódź Town Hall: www.turystycznalodz.pl (12 indications), and www.odkodujlodz.pl (10), the social networking site Facebook (6) and www.rowerowalodz.pl (6). The respondents also indicated www.lodz.naszemiasto.pl (2) and www.prorevita.lodzkie.pl (1). Only $61 \%$ who responded earlier that they had heard about the Łódź Industrial Architecture Trail were able to name a site. This confirms the assumption that the knowledge of many of respondents was very superficial (Fig. 5).

Balle Factory
Winkler \& Gaertnera
Factory
Kindermann Factory
Grohmann Barrels
EC1 Powerhous
Withe Factory
Scheibler Empire
Poznański Empire

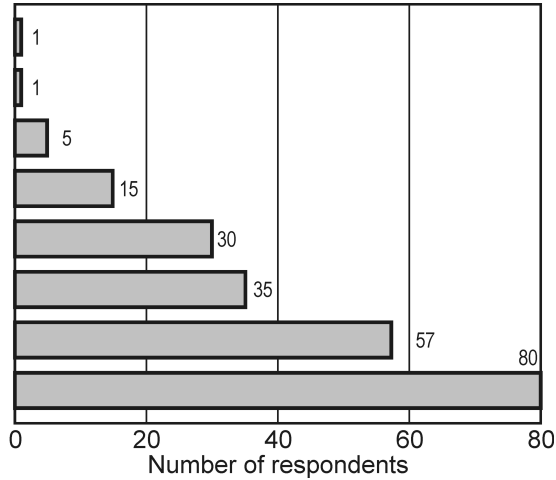

Fig. 5. Sites on the trail identified by the respondents

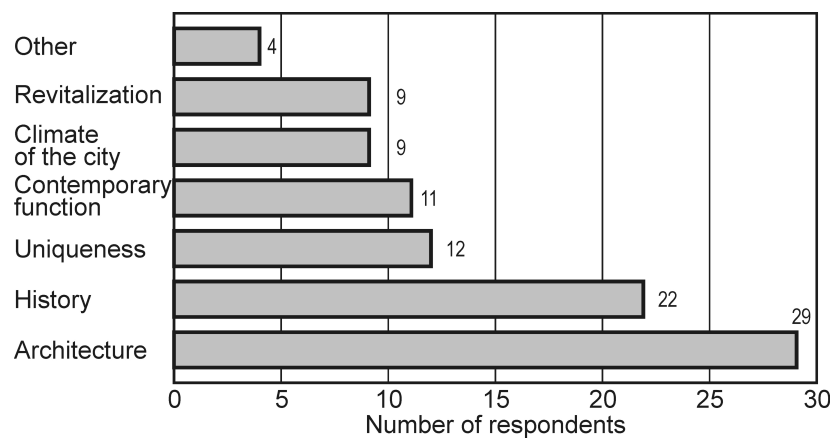

Fig. 6. Justifying the attractiveness of selected sites in the opinion of respondents

The most frequently indicated site on the route was the Poznański 'Empire' (80) followed by the Scheibler 'Empire' (57). The response also included Scheibler
Power station (2), 'famula', (3), fire station (3). The White Factory (35), EC1 (30), Grohmann's Barrels (15) were also mentioned and occasionally Kindermann (5), Winkler \& Gaertner (1) and Joseph Balle Factories (1). Half of the respondents who showed that they heard about the Łódź Industrial Architecture Trail were able to justify why they considered the sites attractive (Figure 6).

Respondents of the indicated sites gave architectural (29) and historical (22) value as justification for attractiveness. For many respondents, the attractiveness of buildings has been demonstrated by their uniqueness in the city, Poland and Europe (12). Their contemporary function (11) and the fact that they create a unique' atmosphere and that they are examples of excellent revitalization. The respondents described sites through such adjectives as beautiful (2), unique (1) and huge (1). Among the justifications were original answers, among them: "when you look at them you can feel the atmosphere of those days when Łódź was an industrial Empire", "a showcase in Poland and abroad", "I lived there and looked at them for years and I know that they create the beautiful history of the city", "they are dominant in the area".

All respondents submitted a proposal for change aimed at enhancing the attractiveness of the Łódź Industrial Architecture Route. No one chose an answer to change nothing on the one hand, as it demonstrates that the trail needs refining and refinement, and on the other hand demonstrates the ingenuity of the people and their interest in the potential tourism product (Figure 7).

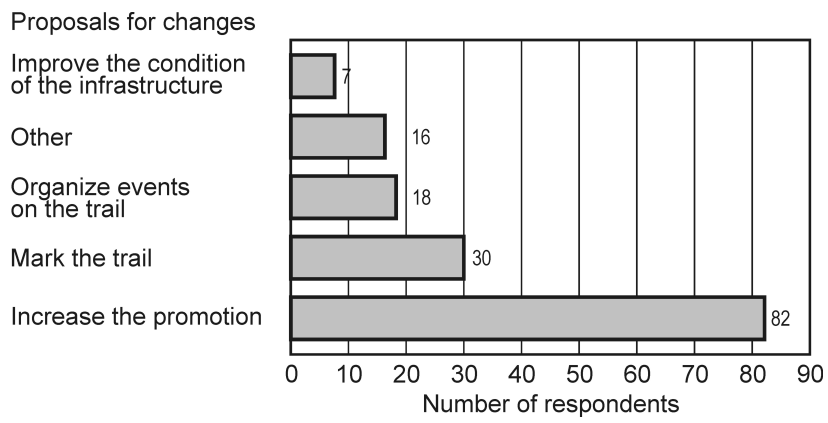

Fig. 7. Proposals for changes aimed at increasing the attractiveness of the trail in the opinion of respondents

The majority of respondents indicated that in order to increase the attractiveness of the trail, it was necessary to intensify its promotion (54\%), mark the trail and set its course (20\%). Respondents acknowledged that a good idea for increasing the attractiveness would be the organization of various events $(12 \%)$ with the improvement of the technical infrastructure (e.g. benches, rubbish bins, bicycle paths) by $5 \%$. Also indicated were their own ideas to increase 
the attractiveness of the trail by marking 'other' (10\%). Most often a mobile application with a guide was proposed, the organization of an annual event related to Łódź factories (e.g. Łódź Factory or Light Move Festivals) (4), and a cycle route (2). Respondents suggested taking care of the appearance of nearby streets and buildings, placing information boards with the trail map, and creating thematic loops on the trail.

A large majority admitted that they had not yet visited the trail, but would like to (71\%). Quite a few said that they had not visited and would not like to visit $(15 \%)$ or that they visited and would like to visit again (13\%). Only $1 \%$ admitted that they had visited and would not want to again. The desire to visit the trail, revealed by $84 \%$, proves the interest of the inhabitants of Łódź in post-industrial sites and their attractiveness, as well as a positive attitude towards the idea of the route. There is a correlation between the age of respondents and attitudes to the trail (Figure 8).

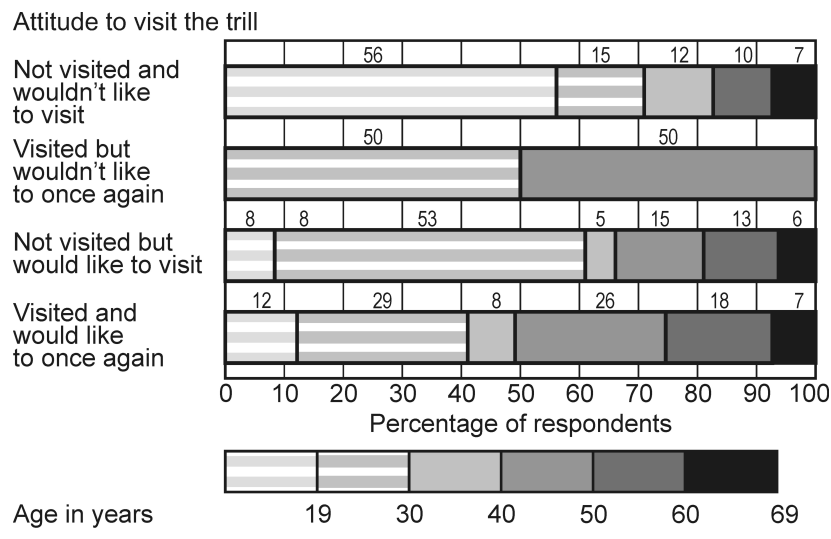

2 The trip is considered to be a visit if it contains at least three sites

Fig. 8. Relationship of respondents to the trail according to age

More than half of those surveyed who showed that they had never visited the trail and did not want to (56\%) were young people - up to 19 years old. This is proof of the relatively low interest in post-industrial sites in the youngest age group. People aged 20-29 (50\%) and 40-49 (50\%) have shown that they have visited the trail but did not want to experience it again. Groups interested in exploring the trail were the most diversified by age, proving that the main determinant in the trail's assessment was the interest and preferences of the respondents.

More than half of the people who would like to visit the trail admitted that they were most interested in its history (54\%) and in exploring post-industrial sites. Respondents also expressed an interest in architecture (33\%) and the function today (13\%).

The largest group admitted that they would like to explore the trail individually $(47 \%)$ or in an organized guided group (42\%). Relatively few respondents would like to be able to visit the trail virtually (9\%). Respondents (2\%) also indicated their own ideas for touring the trail, such as a cycling tour (3) and an organized tour on a historic bus (2).

The vast majority (92\%) admitted that it is worth revitalizing sites that have historically had an industrial function. Only 2\% expressed the opposite opinion. The remaining respondents $(6 \%)$ did not comment on this issue. Age was significant (Figure 9).

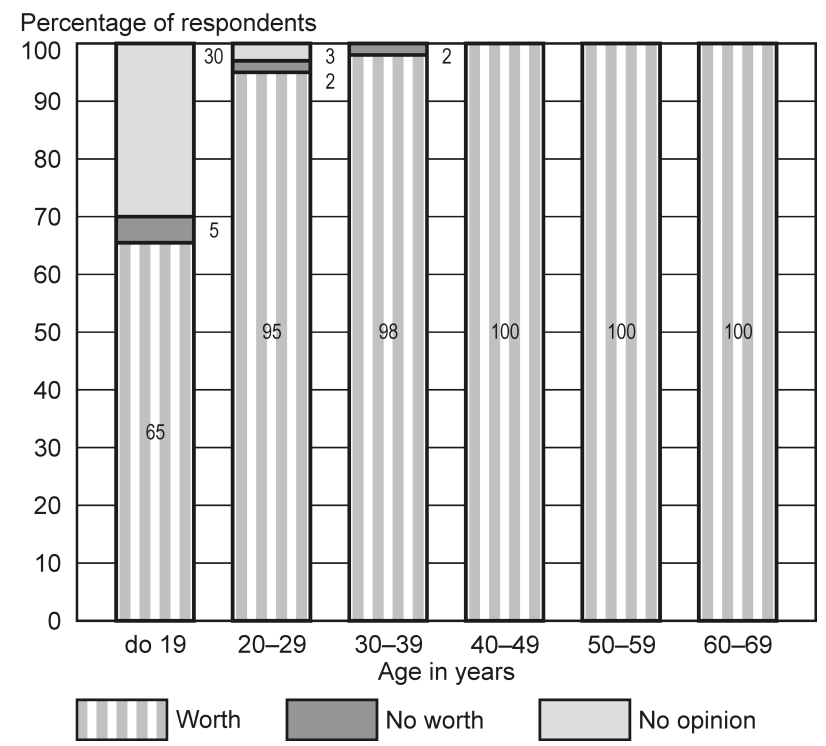

Fig. 9. Opinion of respondents on the revitalization of post-industrial sites

Respondents who considered that it was not worth revitalizing the post-industrial sites were young people up to $19(5 \%)$ and $20-29(2 \%)$. As with the age, the number of responses indicating a lack of opinion decreased (up to $19-30 \%, 20-29-3 \%$ and $30-39-2 \%$ ). At the same time the number who expressed a positive attitude towards revitalization increased (up to 19 - 65\%, 20-29 - 94\%, 30-39 - 98\%, 40-69 - 100\%). This proves that the perception of the benefits of revitalization increases with age, and the process itself is appreciated mainly by adults.

In summary of the results of the study, the evaluation of the trail was mainly based on the personal preferences and subjective perceptions of the respondents. Research has shown that the level of interest in the trail is not influenced by sex or neighbourhood of residence as initially thought by the author. A significant determinant in the perception of the trail, however, was age. The youngest (19 years old) expressed the least favourable attitude towards the trail and the process of revitalization. It is presumed that this is due to the lower level of knowledge of this group of respondents, as well as less experience of life. 


\section{SUMMARY}

Having had an industrial function for almost two centuries, Łódź has a huge industrial heritage. Factoryresidential comlexes, created in different architectural styles, production buildings, palaces and villas, and even factory cemeteries constitute the material culture of the region (KACZMAREK, LISZEWSKI \& WŁODARCZYK 2006). Initially, industrial and technical heritage sites were not identified as protected sites with little relevance to the population (KONOPKA 1994). S. LISZEWSKI (1992) confirmed that, despite a huge and well-preserved potential, industrial sites did not attract much interest among the inhabitants of both Łódź and Poland. With the socio-economic development of Poland and the strengthening of democracy, the perception of post-industrial areas has fundamentally changed. Revitalization has become a chance for development. E. SZAFRAŃSKA (2010, pp. 64-5) is of the opinion that "the vast majority of city dwellers, irrespective of their place of residence, perceive the need to revitalize brownfield sites, express their interest in their future, and want to be informed about their action plans and/or specific actions".

Opportunities for restructuring many postindustrial areas came with the introduction of a tourism function. The activities and changes in these areas were due not only to the economic factor but also to the changing motivations and preferences of tourists seeking new forms of tourism. The symbol of this is the transition from $3 \mathrm{~S}$ (sea, sand, sun) to $3 \mathrm{E}$ tourism (excitement, entertainment, education) and $4 \mathrm{H}$ (heritage, handicraft, habitat, history) (KOWALCZYK 2008). A similar problem was presented in an article entitled "Space of free time in post-industrial facilities in Warsaw Praga: an idea for success?"[Przestrzen czasu wolnego w obiektach poprzemystowych na warszawskiej Pradze] (DEREK 2012) which confirms how big opportunities for tourism create post-industrial sites.

Preserved cultural heritage is also of great importance in the education process, through the shaping of social attitudes. This applies above all to the younger generation, who are perceived as rarely recognizing the historical, cultural or architectural value of industrial sites, as confirmed by the research (SZALPUK 2005).

The large number of post-industrial facilities in Łódź is a great potential for tourism development. The industrial architecture trail of Łódź, which with appropriate 'grinding' could be an important tourist attraction of the city, is of great interest. The undoubted advantage is its generally positive perception by the city's inhabitants, so those who should first be aware of its value. Łódź generally is creative towards the development and promotion of the route. Studies have shown that residents have a substantive knowledge of the cultural heritage of the city in which they live, proving that they have a basis for deciding its fate in terms of tourist development.

The author assumed that the impact on perception of industrial sites is occupied by a placeholder in geographical space. This led to the emergence of two opposing hypotheses:

1. The inhabitants of the districts in which the postindustrial sites are located are more appreciative of their value by their daily relationships with them.

2. Residents of neighbourhoods in which postindustrial facilities are not particularly appreciated their potential.

None of this has been confirmed. The age of the respondents was the determinant in the perception of the trail. The youngest (up to 19) were the least accommodating and indifferent about the trail. This was considered a disturbing conclusion in the process of analyzing the role of social participation. Although the cooperation of local authorities with residents is generally assessed positively and is increasingly used today, it also entails the risk of hasty and illconsidered decisions. In public consultation, people can not be competent to make decisions, which can be either caused by a lack of substantive knowledge, emotional immaturity or simply a different worldview. Bad decisions may then be very damaging to the city's development and cause irreversible consequences. It is extremely important to think carefully about the choice of decision makers.

\section{BIBLIOGRAPHY}

BABBIE E., 2005, Badania spoteczne w praktyce, Wyd. Naukowe PWN, Warszawa, 659 pp.

CZAPIŃSKI J., 2009, Diagnoza społeczna 2009. Warunki i jakość życia mieszkańców, Wyd. Vizja Press \& IT, Warszawa, 420 pp.

DEREK M., 2010, Turystyka przemysłowa, [in:] A. Kowalczyk (ed.), Turystyka zrównoważona, Wyd. Naukowe PWN, Warszawa, pp. 188-208.

DEREK M., 2012, Przestrzeń czasu wolnego w obiektach poprzemysłowych na warszawskiej Pradze, [in:] B. Włodarczyk (ed.), Moda na sukces, „Warsztaty z Geografii Turyzmu”, t. 2, Wyd. Uniwersytetu Łódzkiego, Łódź, pp. 49-66.

FRANKFORT-NACHMIAS CH., NACHMIAS D., 2001, Metody badawcze w naukach społecznych, Zysk i S-ka, Poznań, 615 pp.

FRYKOWSKI M., 2005, Zaufanie spoteczne mieszkańców Łodzi, Wyd. Uniwersytetu Łódzkiego, Łódź, 226 pp.

HANDSZUH H., 2005, Tworzenie wzorca jakości dla turystyki dziedzictwa przemysłowego, [in:] T. Burzyński, M. Łabaj (eds.), Dziedzictwo przemystowe jako atrakcyjny produkt dla turystyki i rekreacji. Doświadczenia krajowe i zagraniczne. Materiaty z II konferencji międzynarodowej, Zabrze, 12-13.05.2005, Wyd. GWSH, Katowice, pp. 29-39.

HAUSNER J. (ed.), 1999, Komunikacja i partycypacja społeczna, Małopolska Szkoła Administracji Publicznej Akademii Ekonomicznej w Krakowie, Kraków, 198 pp. 
JASIUK J., 2008, Dziedzictwo przemysłowe. Doceniony element tradycji oraz społecznego i turystycznego wykorzystania w Polsce i w Europie, [in:] W. Kaprowski, F. Midura, J.W. Sienkiewicz (eds.), Dziedzictwo przemystowe Mazowsza i jego rola w turystyce, Zakład Wydawniczy DrukTur sp. z o.o., Warszawa, pp. 13-19.

JĘDRYSIAK T., 2011, Turystyka kulturowa w obiektach poprzemystowych - zagadnienia ogólne, „Turystyka Kulturowa”, 6, Wyd. KulTour.pl, Poznań, s. 8-27.

KACZMAREK J., LISZEWSKI S., WŁODARCZYK B., 2006, Strategia rozwoju turystyki $w$ Łodzi, Łódzkie Towarzystwo Naukowe, Łódź, 129 pp.

KACZMAREK J., STASIAK A., W€ODARCZYK B., 2010, Produkt turystyczny, Wyd. Ekonomiczne SA, Warszawa, 446 pp.

KONOPKA M., 1994, Obiekty przemystowe też moga być zabytkami. Istota ochrony dziedzictwa kultury technicznej, [in:] M. Smoktunowicz (ed.), Rewitalizacja zabytków techniki. Nowe życie w starych zaktadach przemystowych. Materiaty z konferencji, Ośrodek Dokumentacji Zabytków, Warszawa, pp. 15-22.

KOWALCZYK A., 2008, Geografia turyzmu, Wyd. Naukowe PWN Warszawa, $287 \mathrm{pp}$.

KRONENBERG M., 2007, Turystyka dziedzictwa przemysłowego - próba sprecyzowania terminologii, [in:] T. Burzyński (ed.), Dziedzictwo przemystowe jako strategia rozwoju innowacyjnej gospodarki. Materiaty z IV Międzynarodowej konferencji naukowopraktycznej, Zabrze, 6-7.09.2007, Wyd. GWSH, Katowice, pp. 33-41.

KRONENBERG M., 2012, Wptyw zasobów dziedzictwa przemystowego na atrakcyjność turystycznq miasta. Przykład Łodzi, Wyd. Uniwersytetu Łódzkiego, Łódź, 224 pp.

KRUCZEK Z., 2007, Geografia turystyczna, Proksenia, Kraków, $304 \mathrm{pp}$.

LISZEWSKI S., 1992, The industrial city as a tourist centre. The example of Łódź, Turyzm, 2, 1, pp. 9-22.

MIKOS V. ROHRSCHEIDT A., 2008, Turystyka kulturowa. Fenomen, potencjat, perspektywy, Wyd. GWSH Milenium, Gniezno, pp. 51-172.
MiKOS V. ROHRSCHEIDT A., 2010, Regionalne szlaki tematyczne: idea, potencjat, organizacja, Wyd. Proksenia, Kraków, 408 pp.

OCHMAŃSKI A., 2014, Interpretacja dziedzictwa przemysłowego dla potrzeb turystyki edukacyjnej na przykładzie Szlaku Zabytków Techniki Województwa Śląskiego, [in:] K. Widawski, M. Duda-Seifert (eds.), Turystyka przemystowa w kontekście rozwoju zrównoważonego, Instytut Geografii i Rozwoju Regionalnego Uniwersytetu Wrocławskiego, Wrocław, pp. 119-137.

ORŁOWSKI B., 2008, Fenomen turystyki industrialnej, Akademia Humanistyczna im. Aleksandra Gieysztora, Pułtusk-Ciechanów, $60 \mathrm{pp}$

PUTNAM R., 1995, Demokracja w dziataniu. Tradycje obywatelskie we wspótczesnych Wtoszech, Wyd. Znak, Kraków, 324 pp.

STASIAK A., 2009, Zabytki techniki i przemysłu, [in:] A. Stasiak (ed.), Geografia turystyki Polski. Przewodnik do ćwiczeń krajoznawczych, PWE, Warszawa, pp. 89-107.

SZAFRANEK E., 2008, Kapitał ludzki i społeczny w przestrzeni miasta. Przykład Łodzi, [in:] J. Słodczyk, E. Szafranek (eds.), Mechanizmy i uwarunkowania budowania konkurencyjności miast, Uniwersytet Opolski, Opole, pp. 63-77.

SZAFRAŃSKA E., 2010, Rewitalizacja terenów poprzemysłowych Łodzi w opinii mieszkańców miasta, [in:] T. Markowski, S. Kaczmarek, J. Olenderek (eds.), Rewitalizacja terenów poprzemystowych w Łodzi, KPZK PAN, Warszawa, pp. 41-67.

SZALPUK G., 2005, Uwarunkowania i szanse rozwoju turystyki industrialnej na terenie województwa lubuskiego, [in:] T. Burzyński, M. Łabaj (eds.), Dziedzictwo przemystowe jako atrakcyjny produkt dla turystyki i rekreacji. Doświadczenia krajowe $i$ zagraniczne. Materiaty z II konferencji międzynarodowej, Zabrze, 12-13.05.2005, Wyd. GWSH, Katowice, pp. 239-247.

TOMCZAK J., 2013, Szlak kulinarny jako przykład szlaku tematycznego, Prace i Studia Geograficzne, 52, pp. 47-62.

Article received:

15 April 2017

Accepted:

14 June 2017 